\title{
CRIMINAL LIABILITY UNDER THE INTERNAL \\ REVENUE CODE: A PROPOSAL TO MAKE THE \\ "VOLUNTARY" COMPLIANCE SYSTEM
}

\author{
A LITTLE LESS "VOLUNTARY"
}

WALTER T. HENDERSON, JR.†

"I like to pay taxes. With them I buy civilization."
-Oliver Wendell Holmes ${ }^{1}$

\section{INTRODUCTION}

Even if the United States federal income tax system is deemed to be one of legal compulsion rather than voluntary self-assessment, ${ }^{2}$ its efficiency and effectiveness still depend upon the honesty, integrity, and diligence of the taxpayer. ${ }^{3}$ Although

† B.B.A. 1989, M.Acc. 1990, University of Georgia; J.D. Candidate 1993, University of Pennsylvania. I would like to thank Dr. John B. Barrack of the J.M. Tull School of Accounting at the University of Georgia, Professor Reed Schuldiner of the University of Pennsylvania Law School, and Matthew A. Melone and William S. Cummings for their helpful comments and advice on earlier drafts of this Comment. This Comment is dedicated to my parents, for their profound influence on my understanding of tax policy, and Selena Anne Pittman. The author bears complete responsibility for the opinions expressed and any remaining errors.

${ }^{I}$ RANDOLPH E. PAUl, TAXATION FOR PROSPERTY 277 (1947) (quoting Oliver Wendell Holmes).

2 The exact nature of the American tax system is the subject of much debate. See, e.g., Flora v. United States, 362 U.S. 145, 176 (1960) (stating that the income tax system is "based upon voluntary assessment and payment" by the taxpayer); In re Publishers Guild, Inc., $219 \mathrm{Ct}$. Cl. 643, 647 (1979) (reflecting that "ours is not a 'selfassessment' tax system, but a self-computing, self-determining, or self-reporting system of taxation" (quoting Farnsworth \& Chambers Co. v. Phinney, 178 F. Supp. 330, 333 (S.D. Tex. 1959))); Kenneth L. Harris, On Requiring the Correction of Error Under the Federal Tax Law, 42 TAx LAw. 515, 515 (1989) ("[T] he system is not truly voluntary because taxpayers are legally required to report their income and may incur both civil and criminal penalties for failure to do so." ); John A. LeDuc, Improving the Self-Assessment of Federal Income Tax: Recent Legislative Developments, 19 TAX NOTES 1027,1029 (1983) ("The federal income tax system is voluntary . . . in the sense that the assessment and payment of tax is made by the taxpayer in the first instance."). Some taxpayers have not taken such a narrow view of the term "voluntary." See, e.g., United States v. Dunkel, 927 F.2d 955, 955 (7th Cir. 1991) (per curiam) (noting that one taxpayer, a dentist, "decided that income taxes are voluntary and elected not to contribute").

${ }^{3}$ See Couch v. United States, 409 U.S. 322, 335 (1973) (stating that the entire tax system is "largely dependent upon honest self-reporting"); Spies v. United States, 317 U.S. 492, 495 (1943) (stating that the tax "system can function successfully only if those within and near taxable income keep and render true accounts," and that "[i]n 
Congress originally counted on Americans to "cheerfully" support the income tax, ${ }^{4}$ it quickly recognized that honesty and integrity alone would not insure truthful reporting. ${ }^{5}$ Yet, despite the various civil and criminal penalties prescribed by Congress to deter and punish noncompliance, the "tax gap"-the difference between the amount of taxes voluntarily paid by individuals and corporations and the amount that would be collected if the rate of compliance with the tax laws were $100 \%$-continues to grow. ${ }^{6}$ Some predict that the gap will reach $\$ 113.7$ billion in 1992 , which is over onethird of the projected federal budget deficit for the year. ${ }^{7}$ Predictably, Congress, the Internal Revenue Service (the Service), and other interested parties are scrambling for answers to the noncom-

many ways, taxpayers' neglect or deceit may prejudice the orderly and punctual administration of the system as well as the revenues themselves ${ }^{n}$ ); HARRY G. BALTER, FRAUD UNDER FEDERAL TAX LAW 9 (1951) ("The orderly, effective and punctual administration of the federal revenue system ... depends on the continuation of this honesty on the part of the taxpayer." (citation omitted)).

${ }^{4}$ See Chester N. Mitchell, Willingness-to-Pay: Taxation and Tax Compliance, 15 MEM. ST. U. L. REv. 127, 127 (1985) ("The House Ways and Means Committee predicted in 1913 that Americans would 'cheerfully' support and sustain the new federal income tax.").

${ }^{5}$ See Curtis J. Berger, "Voluntary" Self-Assessment? The Unwilling Extraction of Taxpayer Information, 42 U. PITT. L. REv. 759, 760 (1981) (discussing the "arsenal of enforcement and collection powers" Congress has since given the Internal Revenue Service to combat noncompliance).

${ }^{6}$ See, e.g., ABA COMM'N ON TAXPAYER COMPLIANCE, REPORT AND RECOMMENDATIONS 7 (1987) [hereinafter ABA COMPLIANCE REPORT] (graphically depicting the growth in the tax gap from 1973 to 1981); "Make Risks High Enough" So Fewer Will Cheat, U.S. NEWS \& WORLD REP., Apr. 19, 1982, at 46 [hereinafter Make Risks High Enough] (quoting then-Commissioner of the Internal Revenue Service Roscoe Egger, $\mathrm{Jr}$. as stating that the tax gap for 1982 was a projected $\$ 90$ billion and growing).

7 See C.C. Berg, Operating Under the Table, 90 RestauRANT Bus. MAG. 133 (1991), available in LEXIS, Nexis Library, RSTBUS File ("We have projections of a tax gap for the target year of 1992 for the corporate sector of roughly $\$ 31.1$ billion. The individual sector is another $\$ \mathbf{8 2 . 6}$ billion." (quoting IRS Manhattan District Public Affairs Officer Neil O'Keeffe)); see also Karen Riley, Corporate Tax Dodges Surging, WASH. TIMES, Apr. 18, 1991, at C1 ("In 1992 the Internal Revenue Service has estimated that [the tax gap] will total $\$ 114$ billion-over one-third of the deficit projected for that fiscal year." (quoting Jennie S. Stathis, General Accounting Office Director of Tax Policy and Administration Issues)). One commentator notes that because of the underground economy, approximations of the compliance gap are rough estimates and "obviously suspect." Michael J. Graetz \& Louis L. Wilde, The Economics of Tax Compliance: Fact and Fantasy, 38 NAT'L TAX J. 355, 356 (1985) ("Despite the relatively long history of these efforts [by both the Service and the private sector to measure noncompliance], it is not unfair to say that empirical uncertainties still abound."). Most observers suggest, however, that the errors contained in these estimates tend to err on the conservative side. See id. at 356-57 (detailing reasons why the empirical data would tend to underestimate, rather than overestimate, the tax gap). 
pliance problem. ${ }^{8}$ Their efforts have produced a variety of proposed solutions.

Some studies have suggested that the government should encourage compliance by making a moral appeal to taxpayers to pay up. ${ }^{9}$ This approach is attractive in theory, ${ }^{10}$ but has at least two implementational drawbacks. First, "neutralization theory" suggests that taxpayers can reduce the guilt feelings accompanying deviant behavior by employing any of a variety of justifications. ${ }^{11}$ Some experts contend that this neutralization process casts significant doubt on the potential effectiveness of the moral appeal approach

${ }^{8}$ See, e.g.; Compliance Gap: Hearings Before the Subcomm. on Oversight of the Comm. on Finance, 97th Cong., 2d Sess. 127 (1982) [hereinafter Compliance Gap Hearings] (recording the Treasury Department's analysis of Senate Bill 2198, which “takes important steps toward reducing the compliance tax gap as well as preserving the integrity of our voluntary tax compliance system"); ABA COMPLIANCE REPORT, supra note 6 , at 1 (stating that the ABA formed the Commission with the purpose of "recommend[ing] ways of improving compliance with federal income tax laws, with the goal of reducing a tax gap that now appears to exceed $\$ 100$ billion per year"); Byron L. Dorgan, Narrowing the \$100 Billion Tax Gap, 37 TAX NoTEs 925, 925 (1987) (stating that Congressman Dorgan of North Dakota "formed a bipartisan task force of tax professionals . . . to study the $\$ 100$ billion tax gap and to recommend measures by which the tax gap could be narrowed").

${ }^{9}$ See, e.g., Robert Mason \& Lyle D. Calvin, Public Confidence and Admitted Tax Evasion, 37 NAT'L TAX J. 489, 495 (1984) (stating that "the use of moral suasion to obey tax laws" is a promising strategy for combatting noncompliance).

${ }^{10}$ See id. at 495 (stating that "[m]oral commitment to obey the law . . . is even a stronger incentive" than threats of punishment).

${ }^{11}$ See Quint C. Thurman et al., Neutralization and Tax Evasion: How Effective Would a Moral Appeal Be in Improving Compliance to Tax Laws?, 6 LAW \&c POL'Y 309, 310 (1984) (applying neutralization theory to tax evasion). In the tax compliance context, the standard justifications used by taxpayers to neutralize noncompliance are (1) "denial of responsibility" ("It is okay to claim an undeserved tax deduction in the case where you are not really sure what the rule is."); (2) "condemnation of the condemners" ("It is not wrong to fail to report certain income on your tax return since the government passes laws which allow other people to do it. . . ."); (3) "denial of injury" ("It is not so wrong to fail to report certain income since it does not really hurt anyone ... . "); (4) "defense of necessity" ("It is okay not to report income since inflation requires that you hold onto every dollar possible . . . ."); (5) "metaphor of the ledger" ("It is all right to occasionally fail to report certain income or claim an undeserved tax deduction since you are generally a very loyal and law-abiding citizen ...."); (6) "denial of the victim" ("It is not wrong to fail to claim certain income on your tax return since the government is often careless with your tax dollar . . . ."); and (7) "appeal to higher loyalties" ("It is okay to claim undeserved tax deductions or fail to report certain income when you have donated more to charities and worthy causes than you are allowed to deduct ...."). Id. at 315; see KARYL A. KINSEY, THEORIES AND MOdels of TAX CheATING 22 (American Bar Foundation Working Paper No. 8717, 1988); see also Peter Dean et al., Taxpayers' Attitudes to Income Tax Evasion: An Empirical Study, 1980 BRIT. TAX REV. 28, 33-36, 42 (discussing the interrelationship between tax evasion and taxpayers' perception of the taxing system). 
and may render it virtually ineffective. ${ }^{12}$ Second, there is the possibility of "backfire." 13 The concern here is that making broad appeal to the public-possibly by implementing a "Just Say Nol" campaign-may only have the effect of alerting honest taxpayers that others are either simply not complying or cheating. Consequently, “[a] moral appeal to the public designed to increase tax compliance might backfire by providing yet another neutralization strategy to justify tax evasion: If everyone else is cheating on their taxes, then why shouldn't I? ${ }^{n 14}$ Given the effects of neutralization theory and the potential for backfire, ${ }^{15}$ the moral appeal approach cannot be solely depended upon to remedy the compliance problem.

Another recommendation has been to mount a public relations campaign that would educate the public about the tax system and increase the public's respect for it and the Internal Revenue Service. ${ }^{16}$ Like the moral appeal approach, this proposal also has allure but suffers from potential implementation problems. The

12 See Mason \& Calvin, supra note 9, at 495 ("Neutralization of compliance norms ... may well negate moral suasion efforts and the effect of neutralization on compliance with tax laws is deserving of further study."); see also Thurman et al., supra note 11, at 324 (" $[\mathrm{T}]$ he use of neutralization strategies significantly reduces the inhibiting effect of the threat of guilt feelings on tax evasion.").

${ }^{13}$ See Thurman et al., supra note 11 , at 325 (noting that in a classroom experiment a moral appeal not to cheat alerted the honest that others were cheating with the effect of causing them to cheat as well).

${ }^{14} I d$.

15 Neutralization theory and backfire are not the only problems with implementing the moral appeal approach. Other complications include the perceptions of honest and diligent taxpayers who already know that others are not complying or cheating and who may see the moral appeal as an attempt to "beg" noncompliers to pay. If the government is seen as "begging" noncompliers into compliance, honest taxpayers' perceptions of the integrity of the tax system and the Service could be weakened substantially.

Additionally, the effects of the political climate in which a moral appeal is made must be recognized. For example, an appeal to taxpayers to "pay your fair share" is far more likely to have a positive impact during times of intense patriotism than in times of economic recession. Cf. Floyd K. Haskell, Tax Compliance $\mathcal{E}$ Tax Fairmess, 27 TAX NoTES 839, 842 (1985) ("Americans are patriotic. Given the chance, Americans will choose their country over self-interest."). For any appeal to obtain optimal results, it must be properly timed, and the duration of its effectiveness is largely out of the control of the body making it.

${ }^{16}$ See ABA Section of Taxation, Report of the Second Invitational Conference on Income Tax Compliance, 42 TAX LAW. 705, 727 (1989) (recommending public relations efforts to increase compliance "by appeals to social conscience and by increasing taxpayer awareness of the possibility of detection and sanctions"); see also ABA COMPLIANCE REPORT, supra note 6, at 37 (calling for a "destigmatiz[ation of] the Service among taxpayers" and a "more positive and understanding attitude towards the public among Internal Revenue Service personnel"). 
two major problems with this proposal appear to be the cost of informing the public of the sanction structure and the inherently adversarial role of the Service in enforcing compliance with the tax laws. ${ }^{17}$ Thus, an effort to improve the image of the tax system cannot, by itself, seriously be expected to close the compliance gap.

Still others favor the expansion of the traditional responses to noncompliance, such as greater reporting requirements, increased taxpayer services, and more audits. ${ }^{18}$ Each of these mechanisms can be of only marginal significance, however. Few areas are not already subject to information reporting, ${ }^{19}$ and historical evidence indicates that increased reporting requirements are not likely to increase compliance significantly unless other measures are taken to ensure that taxpayers take those requirements seriously. ${ }^{20}$ Recommendations for increased services and audits ignore political pressure to decrease the Service's budget, ${ }^{21}$ and while these

17 See ABA COMPLIANCE REPORT, supra note 6, at 19-20.

${ }^{18}$ See, e.g., id. at 23-53 (recommending all of these approaches); Dorgan, supra note 8, at 927-29 (same, in addition to tax simplification); see also Jeffrey A. Dubin et al., Penny-Wise and Pound-Foolish: New Estimates of the Impact of Audits on Revenue, 35 TAX NOTES 787 (1987) (advocating stepped-up auditing efforts); Gene Steuerle, The Heyday of the Comprehensive Individual Audit Is Over, 53 TAX NOTES 859, 860 (1991) (advocating further expansion of third-party information reporting).

${ }^{19}$ See, e.g., ABA Section of Taxation, supra note 16, at 711 (stating that "[t]he Service's large commitment to information-matching programs surely has been successful in terms of immediate revenue yield" but that such programs "may have been counterproductive"); James S. Henry, Noncompliance with U.S. Tax Law-Evidence on Size, Growth, and Composition, 37 TAX LAW. 1, 21 (1983) (noting that information reporting requirements have already been expanded to cover most forms of income).

${ }^{20}$ See, e.g., Compliance Gap Hearings, supra note 8, at 127-28, 137-38, 152, 158 (quoting high-level Service officials as stating before Congress that information reporting cannot in itself close the compliance gap and describing the continued underreporting problems in the areas of tip and dividend income, where information reporting is already required).

21 See, e.g., Dubin et al., supra note 18, at 788-89 (stating that "IRS budgets . . . have been hostage to the limited government philosophy of the Reagan Administration" and that the Reagan Administration proposed severe cuts in staff and funding for the agency); Susan B. Long \& David Burnham, Solving the Nation's Budget Deficit with a Bigger, Tougher IRS: What Are the Realities?, 48 TAX NoTES 741 (1990) (discussing the IRS and budgetary constraints on stepped-up enforcement efforts); Martha Middleton, The Tax Gap: Why Don't People Pay Up?, 69 A.B.A. J. 572, 572 (1983) ("More auditing by IRS agents has been suggested . . . but the plain truth is that there aren't enough agents and resources to do the job."); William E. Williams, Strengthening IRS Examination and Collection Processes by Administrative Changes in Staffing, Training, Deployment, and Technology, in INCOME TAX COMPLIANCE: A REPORT OF THE ABA SECTION ON TAXATION INVITATIONAL CONFERENCE ON INCOME TAX COMPLIANCE 235, 237 (Phillip Sawicki ed., 1983) [hereinafter INCOME TAX COMPLIANCE]. 
mechanisms may have the potential to succeed over the long-term, historical trends suggest that their implementation is unlikely in the near future. ${ }^{22}$

One frequently overlooked possibility is expanded criminal liability. Criminal liability is a powerful incentive to obey the tax laws. ${ }^{23}$ In fact, empirical research indicates that it may be one of the few truly administrable deterrents to noncompliance. ${ }^{24}$ The Internal Revenue Code, ${ }^{25}$ however, provides for criminal sanctions in only a very limited class of cases. ${ }^{26}$ Furthermore, in those areas

${ }^{22}$ See Steuerle, supra note 18, at 859 (discussing the dramatic decline in the audit rate from the mid-1960s, when the rate was an estimated $5 \%$, to $.8 \%$ in 1990).

${ }^{23}$ See Mason \& Calvin, supra note 9, at 489 ("Fear of detection, of punishment or the possibility of public disclosure of one's deviance are strong incentives to obey tax laws.").

${ }^{24}$ Empirical research indicates that criminal punishment is a powerful deterrent to noncompliance with the tax laws. Within the criminal liability context, however, an interesting dichotomy exists. In at least one empirical study, "substantial evidence was found that a non-zero perception of prosecution risk had a powerful deterrent impact ${ }^{n}$ on noncompliance. Steven Klepper \& Daniel Nagin, Tax Compliance and Perceptions of the Risks of Detection and Criminal Prosecution, 23 LAW \& Soc. REv. 209, 239 (1989). On the other, researchers have found no meaningful correlation between the perceived severity of formal sanctions and deterrence. See id. at 238-39 (noting that "[f] ew studies in the extensive deterrence literature have found evidence of a deterrent effect of perceived severity of formal sanctions" and that "the long series of negative findings concerning perceived severity led Jensen et al. (1978) to conclude that the perceived severity of formal sanctions had no consequential deterrent effect" (citing Gary F. Jensen et al., Perceived Risk of Punishment and Self-Reported Delinquency, 57 SOCIAL FORCES 57 (1978))). The most plausible reasons for the dichotomy are either the fixed costs associated with defending a criminal prosecution, see id., or the fixed level of stigma that attaches to any level of criminal liability, see Anne D. Samuels, Reckless Endangerment of an Employee: A Proposal in the Wake of Film Recovery Systems to Make the Boss Responsible for His Crimes, 20 U. MICH. J. L. REF. $873,893 \mathrm{n} .112$ (1987) ("Moral blame associated with a criminal conviction can be an effective deterrent ...."). Although the reasoning behind the effect is significant, for the purposes of this Comment, the existence of the dichotomy is what is important.

The upshot of these conclusions is the following: if a taxpayer perceives a nonzero risk of criminal prosecution for a given activity, recognized as noncompliance, then that taxpayer will be less likely to engage in that type of behavior. Intuitively, there are at least two ways to increase that risk for a given taxpayer. One is to enforce the existing criminal provisions more vigorously and to prosecute more taxpayers for engaging in "criminal" behavior. This method, however, should only affect taxpayers who perceive themselves as engaging in behavior that is now recognized as "criminal" - namely, only "willful" behavior under I.R.C. \$§ 7201-7207 (1988). Another way to increase the perceptions of prosecution risk would be to increase the scope of criminal liability to encompass a larger variety of noncompliance. This latter approach is examined in this Comment.

2526 U.S.C. \$§ 1-9602(b) (1988 \& Supp. 1989).

${ }^{26}$ The Internal Revenue Code's criminal provisions are contained in subchapter 
A of chapter 75, or $\$ \S 7201-7232$. The primary provisions for the purposes of this Comment are those contained in \$§ 7201-7203, 7206(1), and 7207.

Section 7201, a felony provision, prohibits tax evasion:

Any person who willfully attempts in any manner to evade or defeat any tax imposed by this title or the payment thereof shall, in addition to other penalties provided by law, be guilty of a felony and, upon conviction thereof, shall be fined not more than $\$ 100,000(\$ 500,000$ in the case of a corporation), or imprisoned not more than 5 years, or both, together with the costs of prosecution.

I.R.C. $\$ 7201$ (1988). As the text provides and the Court has held, tax evasion consists of three elements: (1) "willfulness;" (2) a tax deficiency; and (3) an affirmative act of "evasion" or "attempted evasion." See Sansone v. United States, 380 U.S. 343, 351 (1965).

Section 7202, another felony provision, prohibits the "willful" underpayment of tax:

Any person required under this title to collect, account for, and pay over any tax imposed by this title who willfully fails to collect or truthfully account for and pay over such tax shall, in addition to other penalties provided by law, be guilty of a felony and, upon conviction thereof, shall be fined not more than $\$ 10,000$, or imprisoned not more than 5 years, or both, together with the costs of prosecution.

I.R.C. $\$ 7202$ (1988).

Section 7203 prohibits the "willful" failure to file a tax return:

Any person required under this title to pay any estimated tax or tax, or required by this title or by regulations made under authority thereof to make a return, keep any records, or supply any information, who willfully fails to pay such estimated tax or tax, make such return, keep such records, or supply such information, at the time or times required by law or regulations, shall, in addition to other penalties provided by law, be guilty of a misdemeanor and, upon conviction thereof, shall be fined not more than $\$ 25,000$ ( $\$ 100,000$ in the case of a corporation), or imprisoned not more than 1 year, or both, together with the costs of prosecution.

I.R.C. $\$ 7203$ (1988). Section 7203, as the text indicates, is a misdemeanor provision, unlike $\$ \$ 7201$ and 7202.

Section 7206(1), a felony provision, prohibits "false declarations." It provides: Any person who. . . [w]illfully makes and subscribes any return, statement, or other document, which contains or is verified by a written declaration that it is made under the penalties of perjury, and which he does not believe to be true and correct as to every material matter ... shall be guilty of a felony ....

I.R.C. $§ 7206(1)(1988)$.

Section 7207, another misdemeanor section, prohibits the submission of false documents:

Any person who willfully delivers or discloses to the Secretary any list, return, account, statement, or other document, known by him to be fraudulent or to be false as to any material matter, shall be fined not more than $\$ 10,000 \ldots$ or imprisoned not more than 1 year, or both.

I.R.C. $\$ 7207$ (1988).

The common element for all tax crimes in sections 7201-7207 is the element of "willfulness." Under Cheek v, United States, 111 S. Ct. 604, 911-13 (1991), and 
where the Code does provide for criminal sanctions, the Supreme Court has chosen to interpret the "willfulness" element very narrowly-so narrowly that one scholar comments: "Proving that a tax understatement was characterized by the requisite knowledge and deliberate behavior is an extremely difficult matter and, in . practice, renders the criminal sanction ineffective for all but a very few cases. ${ }^{27}$ The propriety of this restriction on criminal penalties by the courts will be examined in this Comment.

The position of this Comment is that a mild expansion of the existing criminal sanctions to reach reckless ${ }^{28}$ noncompliance ${ }^{29}$ may have an appropriate role in our tax system. A few points,

United States v. Bishop, 412 U.S. 346, 359-61 (1973), "willfulness" has the same meaning for all tax crimes. For a more detailed analysis of the criminal provisions of the Code, see Substantive Tax Crimes and Related Offenses, 162 TAX MGMT. (BNA) (2d), § A, 1105.

${ }_{27}$ Graetz \& Wilde, supra note 7, at 358 (citation omitted). And under the Court's most recent restatement of the doctrine, see infra notes $35-43$ and accompanying text, the "willfulness" burden may be even more difficult for the government to carry. In the words of one jury foreman of a recent post-Cheek case: "A number of people who voted not guilty truly thought [the defendant] was running around the law, but [we could not convict] because of the evidence and the instructions of the judge. I think it is going to be very tough for prosecutors [to obtain convictions in tax crime cases]." Howard Mintz, First Tax Case Under New Rules Ends in Acquittal; Appellate Precedents Swayed Outcome, Jury Foreman Says, REcoRDer, July 26, 1991, at 1, available in LEXIS, Nexis Library, RECRDR File (quoting jury foreman David Holland).

28 "Reckless," for purposes of this proposal and as used throughout this Comment, means that the taxpayer "consciously disregards a substantial and unjustifiable risk that the material element exists or will result from his conduct." MODEL PENAL CODE $\$ 2.02$ (c) (1962). The application of "recklessness" in this proposal differs, however, from its usual context in that it applies to an actor's uncertainty regarding the law rather than the actor's uncertainty regarding factual circumstances. See infra note 29.

${ }^{29}$ Noncompliance, with regard to the tax laws, means that a taxpayer has not remitted the full amount of taxes due the government in accordance with the Internal Revenue Code, and broadly speaking, includes a failure to pay amounts that the taxpayer has reported but not paid. See KarYL A. KINSEY, SURVEY Data ON TAX COMPLIANCE: A COMPENDIUM AND REview 1 (American Bar Foundation Working Paper No. 8716, 1984). This Comment, however, will focus only on the initial steps in the "voluntary" compliance system-the self-assessment aspect.

"Reckless noncompliance," as used in this Comment, is defined in Part II.A., primarily by way of example. The concept is essentially composed of two elements: (1) a subjective awareness on the part of the taxpayer that she is unsure what the law requires in a particular instance; and (2) a lack of effort, or "due diligence," on her part to discover-by looking exclusively to "authoritative sources"-what the law is. Although under the Court's formulation of the "willfulness" doctrine such conduct is not within the range of criminally punishable conduct, see infra notes $64 \& 81$ and accompanying text, many researchers may nonetheless consider this conduct "cheating," see infra note 80 (reproducing a question posed to a sample on the issue of "tax evasion"). 
however, must be made clear from the outset. First, this Comment focuses on the individual, self-preparing taxpayer. ${ }^{30}$ The effects of this proposal, if any, on paid tax-return preparers are not considered. ${ }^{31}$ Second, although a vast array of civil penalties are available under the Code, an analysis of these provisions is beyond the scope of this discussion, and for the most part, they are therefore ignored in this Comment. ${ }^{32}$ Third, this Comment is not seeking to promote the "wholesale application to tax crimes ... concepts inappropriate to the unique characteristics of such crimes, ${ }^{\text {"33 }}$ which is feared by some experts. Rather, it attempts to analyze the current boundaries of criminal liability under the tax law and to determine whether, in light of the policies and purposes of the taxing system, these boundaries are appropriate. Finally, implementing the proposal depends on continuing conventional enforcement

${ }^{30}$ Although no specific estimates regarding the portion of the tax gap attributable to the individual, self-preparing taxpayer can be found, underreporting of the tax liabilities of individuals composed over 83 percent of the total tax gap in 1981, see ABA COMPLIANCE REPORT, supra note 6, at 8-9; see also Berg, supra note 7 (projecting that over $72 \%$ of the gap for 1992 will come from the individual sector), and at least $55 \%$ of the individuals filing returns are self-preparing filers, see Treasury, IRS Seek to Improve Tax Compliance, 25 TAX NOTES 1172 (1984) (noting that IRS estimated that 45 percent of individual returns were prepared commercially). Thus, focusing on issues faced by individual, self-preparing taxpayers would not appear to be unduly narrow.

${ }^{31}$ For a discussion of the theoretical implications involved with paid preparers, see KARYL A. KINSEY, MEASUREMENT BIAS OR HONEST DISAGREEMENT? PROBLEMS OF VALIDATING MEASURES OF TAX EVASION 4-5 (American Bar Foundation Working Paper No. 8811, 1989).

${ }^{32}$ As a side issue, the deterrent effect of conventional civil penalties is unclear. As one report has stated, "results indicate that increases in the probability of a civil fraud penalty are associated with decreases rather than increases in voluntary compliance." Ann D. Witte \& Diane F. Woodbury, The Effect of Tax Laws and Tax Administration on Tax Compliance: The Case of the U.S. Individual Income Tax, 38 NAT'L TAXJ. 1, 8 (1985). The primary reason cited for this effect is the relative secrecy with which these penalties are imposed. See id.; see also ABA COMPLIANCE REPORT, supra note 6 , at 39 ("Deterrence messages will remain limited so long as . . . [t] the Service ... does not have the authority to publicize civil fraud penalties that have successfully been assessed against taxpayers."). Although the penalty provisions, which are notorious for being reworked on a recurring basis, have been substantially revised by IMPACT, the Improved Penalty Administration and Compliance Tax Act of 1989, Pub. L. No. 101-239, §§ 7701-7743, 103 Stat. 2106, 2388-406 (1989) (codified at 26 U.S.C. $\$ 1$ (Supp. I 1989)), the effects of these revisions are relatively unknown. See generally MICHAEL I. SALTZMAN \& BARBARA T. KAPLAN, CIVIL TAX PENALTIES REFORM: ANALYSIS AND STRATEGIES (1990) (discussing IMPACT and the general history of the civil penalty provisions).

${ }_{33}$ ABA, Report of the Committee on Civil and Criminal Tax Penalties, 32 TAx LAw. 895,896 (1979). 
mechanisms, especially the reporting requirements, taxpayer services, and individual audits currently in force.

This Comment is composed of three parts. Part I examines the historical development of the current standard of criminal liability under the Internal Revenue Code, particularly the "willfulness" requirement. Part I also considers the reasons given by the Court for each major stage of the development and attempts to reconcile them with the current liability standard. Part II introduces the concept of the paradigmatic reckless noncomplier. The questions whether, and to what degree, the tax system is suitable to a "recklessness" standard of criminal liability are discussed, as are the features the proposal should contain to ensure consistency with underlying policies and general conceptions of fairness. The political acceptability of the proposal is considered in Part III. Perceived problems are discussed, as are the bases of possible objections.

\section{CRIMINAL LIABILITY UNDER THE INTERNAL REVENUE CODE: STANDARDS AND POLICIES}

Under current law, to be held criminally liable for a substantive violation of the tax laws, a taxpayer must "willfully" commit the proscribed offense. ${ }^{34}$ "Willfulness," however, is susceptible to many different definitions, both within ${ }^{35}$ and outside ${ }^{36}$ the legal context, and the legislative history surrounding the inclusion of the willfulness requirement provides no guidance for a court's choice of a particular meaning. ${ }^{37}$ Consequently, the courts have been forced

${ }^{34}$ See I.R.C. $§ \$ 7201-7207$ (1988 \& Supp. 1990); see also Graetz \& Wilde, supra note 7 , at 358 (stating that "no criminal sanction ... can be imposed absent satisfactory proof that [a] tax understatement was willful"); supra note 26 (describing code provisions utilizing the concept of willfulness).

The criminal provisions of the federal tax statutes have contained a willfulness requirement since 1919. See Joshua Stein, Note, Criminal Liability for Willful Evasion of an Uncertain Tax, 81 CoLUM. L. REV. 1348, $1355 \mathrm{n.47}$ (1981) (tracing the history of the "willfulness" requirement to the Act of Feb. 24, 1919, ch. 18, § 253, 40 Stat. 1085).

${ }^{35}$ See Screws v. United States, 325 U.S. 91, 101 (1945) (stating that "willful' is a word 'of many meanings, its construction often being influenced by its context'") (quoting Spies v. United States, 317 U.S. 492, 497 (1943)).

${ }^{36}$ See WEBSTER'S THIRD NEW INTERNATIONAL DICTIONARY OF THE ENGLISH LANGUAGE UNABRIDGED 2617 (1966) (giving four distinct definitions of "willful").

${ }^{37}$ The virtual lack of legislative history has led the Court to state that ${ }^{~}[t]$ he legislative history of the section contains nothing helpful on the question [of congressional intent]." Spies v. United States, 317 U.S. 492, 495 (1943). 
to 'back into' the meaning of "willfulness" by using various interpretive tools, and by attempting to articulate policies justifying the correct level of culpability for criminal sanctions in the tax context. This Part traces the Court's major interpretations of "willfulness" and, perhaps more importantly, attempts to identify the reasons given for a particular interpretive step.

\section{A. The Current Doctrine}

Under the Court's most recent interpretation of "willfulness," as stated in Cheek $v$. United States, ${ }^{38}$ a criminal violation of the Code's statutory provisions requires the government to prove, among other things, ${ }^{39}$ three separate elements: (1) that a duty existed under the tax laws; (2) that the defendant had actual subjective knowledge of that duty, and (3) that the defendant voluntarily and intentionally violated that duty. ${ }^{40} \mathrm{~A}$ good faith belief-even if that belief is unreasonable or completely irrational-that a statutory duty, as opposed to a constitutional duty, ${ }^{41}$ did not exist will negate the

38111 S. Ct. 604 (1991).

${ }^{39}$ Criminal violations under $\$ \$ 7201-7207$ require the prosecution to prove elements other than willfulness. See supra note 26.

${ }^{40}$ See Cheek, 111 S. Ct. at 610. In Cheek, the Court interpreted "willfully" in the context of $\$ 7201$ (tax evasion) and $\$ 7203$ (willful failure to file). See id. at 606 . The Court held that the meaning of "willfully" in both contexts is the same. Furthermore, under United States v. Bishop, 412 U.S. 346, 359-61 (1973), the Court assumed that "willfulness" in the context of $\$ \S 7201-7207$ has the same general meaning. For purposes of this Comment, this assumption remains in place. A reader desiring a more detailed study of "willfulness" in a particular context, however, should not overlook that, "[t]he lower courts ... have ... joined the Supreme Court in recognizing that 'willful is a word of many meanings, its construction often being influenced by its context." ROBERT M. SCHMIDT, LEGAL AND ACCOUNTING HANDBOOK OF FEDERAL TAX FRAUD 32 (1963) (quoting Spies v. United States, 317 U.S. 492, 497 (1943)). Since methods of proving "willfulness" differ from one case to the next, treating "willfulness" as one unified topic could be misleading. See id. It is hoped that so treating "willfulness" here will not prove confusing, however.

${ }^{41}$ In Cheek, the Court drew this distinction with respect to what legally constitutes a "good faith" claim. On the one hand, the Court concluded that, because of "[t]he proliferation of statutes and regulations," Cheek, $111 \mathrm{~S}$. Ct. at 609, a good faith misunderstanding of the statutory framework of the Code negates willfulness. See id. at 611 . On the other, it concluded that a constitutional claim that the Code was invalid was a "submission[] of a different order. ... not aris[ing] from innocent mistakes caused by the complexity of the Internal Revenue Code," Id. at 612 (citation omitted). As such, the Court held that those claims did not, as a matter of law, constitute a good faith defense sufficient to negate willfulness. See id. at 613 . For a discussion of the potential theoretical difficulties with this distinction, see Jules Ritholz \& David M. Kohane, Supreme Court Finds Subjective Ignorance of the Law a Defense to Criminal Tax Fraud, 74 J. TAX'N 254, 254-55 (1991). 
defendant's knowledge of the duty, and the government will have the burden of disproving such a belief if one is claimed. ${ }^{42}$ Thus, the government carries a heavy burden in proving that a noncompliant act was committed with the requisite element of "willfulness." This interpretation appears to be generally consistent with the Court's prior interpretations, ${ }^{43}$ all of which have the support of persuasive policy rationale.

\section{B. The Policies Underlying The Doctrine}

In developing the current "willfulness" doctrine, the Court has been forced to articulate its motivations. But even though the Court frequently purports to be merely using standard interpretive tools, ${ }^{44}$ the real purposes for the Court's restrictive interpretation of "willfulness" can be derived clearly only by analyzing the Court's opinions.

In United States $v$. Murdock, ${ }^{45}$ the first decision interpreting "willfulness," the Court gave the most obvious reason for its interpretation-the tax law's complexity. In Murdock, the Court recognized that in defining "willfulness" in the tax context it was working with a clean slate; and the Court acknowledged the wide array of meanings that "willfully" could employ. ${ }^{46}$ Although it purported to use a standard tool of statutory interpretation by looking to "the context in which it is used," ${ }^{n 47}$ the Court chose to look to the tax law's complexity and infer an intention on the part of Congress that "a person, by reason of a bona fide misunder-

42 See Cheek, 111 S. Ct. at 611.

${ }^{43}$ See United States v. Pomponio, 429 U.S. 10, 12 (1976) (per curiam) ("[W]illfulness . . . simply means a voluntary, intentional violation of a known legal duty."); United States v. Bishop, 412 U.S. 346,361 (1973) (holding that "willfully" requires more than a showing of careless disregard for the truth); Spies v. United States, 317 U.S. 492, 498 (1943) ("Willfulness ... include[s] some element of evil motive and want of justification in view of all the financial circumstances of the taxpayer."); United States v. Murdock, 290 U.S. 389, 398 (1933) (finding that the statute makes "bad faith or evil intent" an "element of the offense"). Although some commentators have correctly recognized that these definitions of "willfulness" are not identical, see, e.g., Elliot Silverman, Turning the Other Cheek: Tax Fraud, Tax Protest, and the Willfulness Requirement, 69 TAXES 302, 303 (1991) (stating that the "Supreme Court did not definitively settle on a single definition of 'willfulness' until 1976"), these definitions are all consistently restrictive.

${ }^{44}$ See infra notes $46-47$ and accompanying text.

45290 U.S. 389 (1933).

${ }^{46} \mathrm{See} i d$. at $394-95$ (citing a range of cases and discussing various meanings of "willful").

${ }^{47}$ Id. at 395 . 
standing as to his liability for the tax, as to his duty to make a return, or as to the adequacy of [his] records ... should [not] become a criminal by his mere failure to measure up to the prescribed standard of conduct. ${ }^{\$ 8}$ Thus, heavy emphasis was placed on the perceived unfairness of attaching stigma and blame, and inflicting punishment on the innocently mistaken taxpayer.

Another distinct reason for the restrictive definition can be found in Spies $v$. United States. ${ }^{49}$ There, the Court's rationale for reversing a lower court's conviction of a taxpayer for attempted tax evasion was not only the two justifications offered in $M u r d o c k^{50}$ complexity of the tax law and standard statutory construction-but also a "traditional aversion to imprisonment for debt." 51 The Court's reliance on this analogy to debtors' prisons, ${ }^{52}$ however, is subject to legitimate criticisms.

One important distinction is that, under the Code, a tax deficiency is not always a necessary condition for the imposition of criminal liability. For example, in a prosecution for a violation of section 7206(1), willfully committing perjury, a tax deficiency is not even an element of the crime; ${ }^{53}$ rather, the falsehood is the

$48 \mathrm{Id}$. at 396.

49317 U.S. 492 (1943).

${ }^{50}$ In Spies, the Court offered a variation of the "innocently mistaken taxpayer" rationale of Murdock, see supra text accompanying notes $46-48$, by stating that "the law is complicated, accounting treatment of various items raises problems of great complexity, and innocent errors are numerous .... It is not the purpose of the law to penalize frank difference of opinion or innocent errors made despite the exercise of reasonable care." Spies, 317 U.S. at 496 (citation omitted) (emphasis added). The Court also included the contextual interpretation argument with explicit reference to Murdock. See id. at 497-98.

51 Spies, 317 U.S. at 498.

52 For a general discussion of the history of debtors' prisons, see Richard Ford, Imprisonment for Debt, 25 MICH. L. REv. 24, 24-34 (1926).

${ }^{53}$ See, e.g., United States v. Olgin, 745 F.2d 263, 272 (3d Cir. 1984) (filing and subscribing to false corporate income tax returns a crime), cert. denied, 471 U.S. 1099 (1985); United States v. Carter, 721 F.2d 1514, 1539 (11th Gir.) ("Section 7206(1) is a fraud statute and . . . does not require the prosecution to prove the existence of any taxable income."), cert. denied, 469 U.S. 819 (1984); United States v. Garcia, 553 F.2d 432,432 (5th Cir. 1977) (per curiam) (holding that trial court did not err in refusing to permit defendant to introduce evidence of what tax might be owing where issue is false statement); United States v. Ballard, 535 F.2d 400, 404 (8th Cir.) (citing precedent "ma[king] clear that under $\$ 7206(1)$, the Government [does] not need to establish an actual tax deficiency in a $\$ 7206(1)$ prosecution $\left.{ }^{n}\right)$, cert. denied, 429 U.S. 918 (1976); United States v. Jernigan, 411 F.2d 471, 473 (5th Cir.) ("[I]t was not necessary for the Government to prove a deficiency in tax for the years in question."), cert. denied, 396 U.S. 927 (1969); Schepps v. United States, 395 F.2d 749, 749 (5th Cir.) (holding that trial court's refusal to allow evidence that falsity resulted in no 
crime. ${ }^{54}$ But willfulness is an element of all tax crimes. Thus, by restricting the meaning of "willfulness," the Court restricted all forms of criminal liability under the Code, not just those requiring a deficiency, and the Court's "debtors' prison" analogy is overbroad.

Another distinction exists between the traditional debtors' prison case and a tax deficiency. In the former, the debt resulted from a voluntary exchange between the debtor and the creditor, where both parties assumed a certain level of risk. The public's notorious distaste for debtors' prisons may, in part, result from the government's interference with this voluntary risk allocation by imposing the threat of imprisonment upon the defaulting debtor. In the tax context, however, the government imposes the obligation on the taxpayer and since no voluntary transaction occurred, the government cannot be said to have assumed the risk of a taxpayer's default. In other words, the government is an involuntary creditor. ${ }^{55}$ Furthermore, courts frequently allow the threat of imprisonment to loom large in similar contexts where duties to pay are imposed unilaterally by the government. A notable example is an estranged spouse's failure to pay child support. ${ }^{56}$

Finally, although the Court's "traditional aversion to imprisonment for debt" may explain why it dislikes criminal liability for violations of the tax laws in the abstract, it fails to explain its decision to define "willfully" as it did. Taking the baseline rule to be that some level of culpability justifies imprisonment for violations

deficiency was not error), cert. denied, 393 U.S. 925 (1968); Silverstein v. United States, 377 F.2d 269, 270 (per curiam) (1st Cir. 1967) (holding that trial court had not erred in refusing to permit defendant to establish the small amount of additional tax owed where violation of false statement statute was charged).

${ }^{54}$ See, e.g., United States v. Marabelles, 724 F.2d 1374, 1380 (9th Cir. 1984) (noting that the "requisite affirmative acts are established by the filing of the false tax returns"); Gaunt v. United States, 184 F.2d 284, 288 (1st Cir. 1950) ("[T]he subsection's purpose is to impose the penalties for perjury upon those who willfully falsify their returns regardless of the tax consequences of the falsehood."), cert. denied, 340 U.S. 917 (1951).

${ }^{55}$ Cf. Michael R. Arner, The Worthier Creditors (And a Cheer for the King)-Revisited, 53 AM. BANKR. L.J. 389, 391 (1979) (discussing similar arguments made by the Treasury during the adoption of the Bankruptcy Code).

${ }^{56}$ See, e.g., George James, States Using Strict Tactics to Collect Child Support, N.Y. TIMES, Sept. 20, 1989, at B1, B2 (noting that some states are using jail time as an incentive for delinquent fathers to pay child support); Jail Is Okay as Child-Support Weapon, CHI. TRIB., Apr. 28, 1988, at 19 (stating that "[t]he U.S. Supreme Court . . . effectively ratified the procedures most states use to have fathers held in contempt of court and possibly be sentenced to jail for failing to pay child support"). 
of the taxing statutes, as indicated by Congress' enacting sections 7201-7207, the analogy to debtors' prisons seems only to justify defining "willfulness" as something more than strict liability or negligence. ${ }^{57}$ Once the Court evaluates various levels of subjective awareness, the fact that a debt was owed appears to be of little relevance; the crime is the violation of the statute. While it is obvious that the Court used the analogy to debtors' prisons to restrict the scope of criminal liability under the tax law, the propriety of that reliance is suspect.

In United States v. Pomponio ${ }^{58}$ and later in Cheek, ${ }^{59}$ the Court added little to the rationale for limiting the standard for "willfulness" under the tax laws, but it did reaffirm its reliance on the complexity argument in Murdock. In Cheek, the Court stated that the special interpretation of "willfulness" in the tax context is "largely due to the complexity of the tax laws." 60 The Court reintroduced its view that Congress must have intended that innocent mistakes would not be punished. ${ }^{61}$ In view of the Cheek Court's reaffirmation of only those two justifications, and the questionable nature of one of the Court's other purported justifications (the "imprisonment for debt" rationale), the decision to define "willfulness" narrowly in the tax context can be seen as based on a single synthesized justification: the fear that a taxpayer, despite the exercise of reasonable care, will become confused by the tax law and, because of an innocent mistake, be labelled and punished as a criminal. Whether the Court's articulated standard is the best way to protect against that fear and balance the competing policy interests involved, however, is another matter.

Interestingly, the refined standard handed down in Cheek could have anomalous results when reconciled with the Court's other stated policies and the characteristics of the American income tax collection system. As stated previously, the Court's primary reason for narrowing the scope of criminal liability in the tax context was its fear that a diligent taxpayer would be criminally sanctioned "despite the exercise of reasonable care." ${ }^{62}$ The opinion and rule handed down in Cheek, however, fails to encourage the taxpayer

\footnotetext{
${ }^{57}$ For definitions of "strict liability" and "negligence," see infra notes 77-78.

58429 U.S. 10 (1976) (per curiam).

59111 S. Ct. 604 (1991).

${ }^{60} \mathrm{Id}$. at 609.

61 See id. at 609-10.

${ }^{62}$ Spies v. United States, 317 U.S. 492, 496 (1943) (emphasis added).
} 
diligence the Court appears blindly to assume and, indeed, may even discourage a confused taxpayer from seeking answers to her questions. The most notable comment of the Cheek Court on this subject appeared in a discussion of how the knowledge of the defendant in a tax evasion case is to be proven. The Court stated:

Of course, in deciding whether to credit Cheek's good-faith belief claim, the jury would be free to consider any admissible evidence from any source showing that Cheek was aware of his duty to file a return and to treat wages as income, including evidence showing his awareness of the relevant provisions of the Code or regulations, of court decisions rejecting his interpretation of the tax law, of authoritative rulings of the Internal Revenue Service, or of any contents of the personal income tax return forms and accompanying instructions that made it plain that wages should be returned as income. ${ }^{63}$

So, assuming that (1) there is no criminally enforceable duty to read the instructions accompanying federal income tax forms, ${ }^{64}$ and (2) a confused taxpayer is aware that the current standard for imposing criminal liability is that ignorance of the law is an excuse, ${ }^{65}$ this

${ }^{63}$ Cheek, 111 S. Ct. at 611 (footnote omitted).

${ }^{64}$ No case appears to state this rule in "black letter" terms, but this point may be demonstrated easily from the language of Cheek. First, under Cheek an irrational belief may negate willfulness. See supra notes $40-42$ and accompanying text. Second, the Court placed no restrictions on the sources from which that belief could be derived, and it is obvious that an irrational belief held in good faith could be obtained from a large number of sources other than the official instructions. The Courts of Appeals have begun to recognize this. See Tax Division Official Says "Cheek" Decision Given Broad Application by Appeals Courts, WASH. INSIDER, Oct. 29, 1991, available in LEXIS, BNA Library, BNAWI File (detailing how the Cheek decision has broadened the class of evidence that can be introduced in a criminal tax proceeding and discussing other evidentiary issues). Thus, it is clear that there is no requirement for self-preparing taxpayers to even attempt to read the official Service instructions to avoid the threat of criminal prosecution.

65 The notion that the average taxpayer will be aware that the government's burden is extremely heavy is not as far-fetched as it sounds given the enormous amount of publicity that the Cheek decision has generated. A small sampling of the post-Cheek hype-both accurate and inaccurate-includes: Greg Henderson, Court Gives Added Protection to Those Charged with Tax Evasion, UPI, Jan. 8, 1991, available in LEXIS, Nexis Library, UPI file ("The Supreme Court ruled . . . that a sincere belief that tax laws do not apply to a defendant can be used as a defense in a tax evasion trial."); David G. Savage, Tax Protestors Cannot Be Jailed If Beliefs Are Sincere, L.A. TIMEs, Jan. 9, 1991, at A1 ("The Supreme Court made it harder ... for the government to punish tax protestors, ruling that a person who sincerely believes he is exempt from tax laws may not be jailed for a criminal tax violation."); Tax "Protesting" Ruled Not "Willful" Evasion, L.A. TIMEs, Jan. 8, 1991, at P3 ("Americans who refuse to pay their federal income tax because they sincerely believe the tax law is unconstitutional cannot be convicted of 'willful' tax evasion."); Jay R. Weill, Hyped 
passage indicates that reading the Form 1040 instructions or other I.R.S. publications makes it easier for the government to prove, via circumstantial evidence, actual knowledge of the law in the event of a criminal prosecution. For example, if evidence that the taxpayer actually read or even skimmed the relevant instructions is presented in a criminal proceeding, the taxpayer must show not only that her belief with regard to the law was in fact held in good faith, but she will also have to refute the logical presumption that she became aware of the law by reading the instructions. In other words, for the truly confused taxpayer, reading the instructions and getting the answer wrong ${ }^{66}$ only makes it more difficult to demonstrate innocence.

Conversely, it could be argued that the requirement of "good faith" on the part of the taxpayer imposes a duty to read the instructions or, at least, to be aware of the most obvious provisions of the law. ${ }^{67}$ But such an argument proves too much for at least two reasons. First, in Cheek, the Court held that before a taxpayer can be found to have "willfully" committed a noncompliant act, the government must prove that a positive, affirmative duty in fact exists. ${ }^{68}$ Since there is, in fact, no duty to read the instructions, the taxpayer cannot be guilty of violating that "duty." Second, the Court stated that any belief that a statutory duty did not existhowever unreasonable-if genuinely held, negates knowledge. This would appear equally applicable to any duty which could be imposed under the tax law, including a duty to become aware of the law itself. Consequently, a more stringent interpretation of "good faith" cannot be depended upon to remedy the problem, and any finding that a taxpayer is criminally liable because she failed to read the instructions is simply an incorrect application of the law.

Reports of Court Rulings May Spawn Suits, N.J. L.J., Jan. 31, 1991, at 9 (stating that one "radio announcer declared the decision to be a victory for the tax-protest movement"). Additional danger and complexity results from the fact that during the hysteria of the celebration, many of those publicizing the opinion read it wrong. See id. (stating that a radio comment publicizing the opinion "bore no resemblance" to the Court's actual holding). text.

${ }^{66}$ This is a very real fear for the Court. See supra notes 58-60 and accompanying

${ }^{67}$ Cf. Jonathan Eisenberg, "Willful Violations" of the Federal Securities Laws: Why" the SEC's No-Fault Approach Is Now Ripe for Rejection, LAW \& BUS. INSIGHTS (Prentice Hall), Aug. 1991, at $13 \& \mathrm{n} .49$ (reviewing the Cheek decision and stating that, "[ $\mathrm{t}]$ he Court did not address whether recklessness would be sufficient to negate good faith").

${ }^{68} \mathrm{See}$ Cheek, $111 \mathrm{~S}$. Ct. at 610 . For a discussion of the elements of willfulness, see supra notes 35-43 and accompanying text. 
Therefore, although the Court's reasons for narrowing criminal liability in the tax context are the result of very real concerns, the standard articulated by the Court at least arguably, goes too far and may very well discourage confused taxpayers from voluntarily seeking answers to their questions. Accordingly, a refined level of criminal liability should be considered.

\section{The Proposal}

As discussed above, the current standard for the imposition of criminal liability under the tax law is fundamentally inconsistent with both the policies from which it is derived and the characteristics necessary for the efficient administration of the American income tax system. ${ }^{69}$ Consequently, in the context of the narrow scope of liability for noncompliant acts allowed by the Court, there are really only two alternatives available to remedy the problem: (1) altering the standard for criminal liability under the Code; or (2) doing away with criminal liability entirely. This Comment chooses the former for two reasons.

First, it is readily acknowledged that to enforce the tax laws as they are to be administered under the American system, "[a] punishment component is essential" in the penalty structure. ${ }^{70}$ The trick, of course, is to select the appropriate amount of punishment and create sufficient incentives to reinforce compliance norms. ${ }^{71}$ In other words, though punishing deviance is necessary in our "voluntary" system, the level of punishment imposed should not breed resentment ${ }^{72}$ or cause taxpayers to search inefficiently for answers to their questions; taxpayers should be truthful but, at the same time, should not be needlessly intimidated or overworked. To the extent that these attributes can be achieved, policymakers ought to strive to do so. But the important point is the recognition that a punishment component is indeed necessary.

Second, and perhaps more importantly, some level of criminal liability for some violations of the tax laws should exist simply

${ }^{69}$ See supra notes 58-68 and accompanying text.

70 ABA COMPLIANCE REPORT, supra note 6, at 22.

71 See Mark H. Moore, On the Office of Taxpayer and the Social Process of Taxpaying, in INCOME TAX COMPLIANCE, supra note 21, at 275, 283 (noting that "if enforcement alone is expanded, the norms supporting tax compliance may deteriorate even more quickly").

${ }^{72}$ Cf. Mason \& Calvin, supra note 9, at 494-95 (stating an empirical preference for compliance efforts that do not create "resistance" to the tax laws). 
because it is the will of the people, as evidenced by the existence of I.R.C. sections 7201-7207. Congress is composed of democratically elected representatives who, by enacting the predecessors of sections 7201-7207, merely carried out the will of the electorate. Since these provisions have not been repealed, they should be accorded considerable deference. Unless some flaw can be found in the political process that allowed these provisions to be enacted, it should be presumed that there is legitimate public support for some level of criminal deterrence and punishment for noncompliance with the tax law. ${ }^{73}$

Therefore, assuming that some level of criminal liability under the taxing system is desirable, we must recognize that the Supreme Court-not Congress-has been primarily responsible for defining what constitutes a criminal act under the Code. ${ }^{74}$ Although the policies articulated by the Court in developing the current standard appear valid, it is contended that the resulting standard is not appropriate. What follows is a proposal for a more appropriate standard for liability under the Code-one which would be fair to the individual taxpayer, the tax system, and the public at large.

\section{A. Understanding Noncompliance: The Paradigmatic Case of the Reckless Noncomplier}

Although it would be nice if all taxpayers agreed with Mr. Justice Holmes's comment about his fondness for taxes, ${ }^{75}$ such an expectation is unrealistic. It is not unrealistic, however, for society to demand, through the criminal law, that there be some absolute minimum duty to at least attempt to comply with the tax laws. This Comment draws the line for that absolute minimum at a standard of recklessness. ${ }^{76}$ By recklessness, this Comment means exactly that-not strict liability, ${ }^{77}$ not negligence, ${ }^{78}$ but recklessness. To

73 The argument that the presence of open political processes is the best criterion for reviewing a statute is most closely associated with John Hart Ely. See JoHN H. ELY, DEMOCRACY AND DISTRUST 73-104 (1980).

${ }_{75}$ See supra notes $34-43$ and accompanying text.

75 See supra text accompanying note 1 .

76 For the meaning of "recklessness" as used in this Comment, see supra note 28.

77 "Strict liability," as used in the criminal law, is generally understood to mean liability without regard for fault. See 1 WAYNE R. LAFAVE \& AUSTIN W. SCOTT, JR., SUBSTANTIVE CRIMINAL LAW \$ 3.8 (1986).

78 The Model Penal Code defines "negligence" as follows:

A person acts negligently with respect to a material element of an offense when he should be aware of a substantial and unjustifiable risk that the 
make the meaning of recklessness plain, consider the following hypothetical: Taxpayer $T$ is completing her income tax return for the immediately preceding taxable year. In doing so, she comes to line six-the dependency exemption line. In determining whether her son, twenty-seven years of age and a full-time student with gross income over the prescribed limit, is a person for whom she is eligible to claim an exemption, she travels through the following thought processes. First, she realizes that she is not sure what the rule governing this situation is, and she cannot remember whether she claimed him last year. Second, she realizes either that there is a rule covering the situation or that there is a substantial likelihood that there is a rule governing the situation, and, in either instance, that the rule could probably be found by looking through the instructions. Then, she determines that it is simply not worth the bother to attempt to look the rule up and, taking the benefit of the doubt, she claims him. Here, $T$ has met all of the requirements of the reckless noncomplier: she disregarded a substantial and unjustified risk that she was violating the tax laws, and chose to act in violation of the law anyway. ${ }^{79}$

material element exists or will result from his conduct. The risk must be of such a nature and degree that the actor's failure to perceive it, considering the nature and purpose of his conduct and the circumstances known to him involves a gross deviation from the standard of care that a reasonable person would observe in the actor's situation.

MODEL PENAL CODE $\$ 2.02$ (d) (1962). The critical distinction between negligence and recklessness under the Model Penal Code is the actor's awareness of the risk. See 1 LAFAVE \& SCOTT, supra note 77, at \$ 3.7.

${ }^{79} \mathrm{~A}$ major debate in the compliance literature concerns defining taxpayer behavior. As LeDuc explains:

The application of [the noncompliance] analysis to the efforts to improve the self-assessment system requires a further injection of theory because of the uncertainty that surrounds the "voluntariness" of compliance. In particular, is the paradigm of noncompliance the taxpayer who seeks to selfassess fairly but who, through lack of diligence or carelessness, omits reportable income or overstates deductions? Or is the paradigm of noncompliance the taxpayer who will fairly self-assess only if he believes that the risk of the penalties for being apprehended exceeds the potential rewards of compliance?

LeDuc, supra note 2, at 1029 (citations omitted).

Robert Melia provides one of the most concise descriptions of the various models of taxpayer compliance. See Robert M. Melia, Is the Pen Mightier Than the Audit?, 34 TAX NOTES 1309, 1309-10 (1987). The models described in his analysis are: (1) the economic model; (2) the uncertainty model; (3) the norms of compliance model; and (4) the inertia model. See id. The "paradigmatic noncomplier" described in this Comment does not fit any one of Melia's models, but can be described as a combination of the last three. For other discussions of the theories of taxpayer 
Before considering the appropriateness of imposing criminal sanctions on the reckless noncomplier, two important observations should be made. First, evidence suggests that behavior like that in the hypothetical may be typical for some taxpayers. ${ }^{80}$ Second, it is plain that $T$ would not be subject to criminal sanctions under current law since she did not knowingly violate the relevant provisions of the Code. ${ }^{81}$ Although this particular example is a thought experiment, a large number of actual taxpayers are probably acting in a similar manner without the threat of criminal sanctions.

In considering the fairness of criminally punishing the reckless noncomplier, it is important to first consider the fears articulated by the Court in its own development of the "willfulness" doctrine: the fear that the innocent, diligent, but confused taxpayer would commit an error and, as a result, become a criminal. This concern is a very real one, and given the enormous complexity of the Code, fairness dictates that simple errors should not result in criminal liability. Punishing innocent mistakes with criminal sanctions would also do little to improve compliance, since innocent errors are unlikely to be deterred. For expanded criminal liability to be fair, therefore, there must be a second component: a "due diligence" component.

This due diligence requirement could protect against the imposition of liability when the jury finds that the defendant took appropriate steps to consult authoritative resources as necessary under the circumstances. For most taxpayers, resort to the Form 1040 instructions likely would be sufficient. ${ }^{82}$ By allowing the jury

behavior, see KINSEY, supra note 11; KENT W. SMITH \& KARYL A. KINSEY, UNDERSTANDING TAXPAYING BEHAVIOR: A CONCEPTUAL FRAMEWORK WITH IMPLICATIONS FOR RESEARCH (American Bar Foundation Working Paper No. 8724, 1988).

${ }^{80}$ See, e.g., Thurman et al., supra note 11, at 315 (finding that 61.4 percent of people surveyed did not strongly disagree with the following statement: "It is okay to claim an undeserved tax deduction in the case where you are not really sure what the rule is ...." ).

81 For a discussion of the necessary elements of "willfulness" under current law, see supra notes $35-43$ and accompanying text. Case law indicates that a mere showing of recklessness will not suffice for a criminal tax conviction. See, e.g., United States v. Fletcher, $928 \mathrm{~F} .2 \mathrm{~d} 495,502$ (2d Cir.) ( $[$ [T] he jury was properly warned that reckless ignorance of the tax law does not constitute willful intent to violate the law."), cert. denied, 112 S. Ct. 67 (1991); United States v. Eilertson, 707 F.2d 108, $109-10$ (4th Cir. 1983) (reversing a lower-court case tried on the ground that equating willfulness with "careless and reckless disregard" was error under United States v. Bishop, 412 U.S. 346 (1973)); United States v. Wolters, 656 F.2d 523, 525 (9th Cir. 1981) (stating that the term "willful" properly excludes "reckless disregard").

82 Ideally, the "due diligence" component would take into consideration all of the 
to determine if the taxpayer, considering all of her relevant characteristics, took appropriate steps to investigate a conscious inquiry, the fears of the Court and the public-at-large could largely be laid to rest.

\section{B. The Propriety of Criminally Punishing the Reckless Noncomplier}

In considering the appropriateness of criminally punishing the reckless noncomplier, the first point that should be addressed is an obvious one: Is the tax system conducive to the imposition of a "recklessness" standard?

The mere mechanics of the tax system make it conducive to a recklessness standard. As one researcher has noted, "[u]nlike other crimes-even economic crimes-tax compliance requires a report-a tax return-through which the taxpayer directly conveys a significant amount of information to the cognizant law enforcement agency." 83 The distinction is critical; it emphasizes how tax compliance, as opposed to other duties prescribed by statute (such as obeying speed limits or stopping at traffic lights) involves clear and unmistakable instances where the taxpayer must take affirmative steps to answer questions plainly posited to her. These questions should, for most taxpayers, trigger subjective inquiries into what the law is and how the law is to be applied to her particular situation. Granted, this prompting is more clearly demonstrated in the realm of taking deductions (an affirmative step), than in forgetting to report income (which may occur by omission), but implementing

relevant factors concerning the defendant, such as education or personal experience with tax matters, to determine what would be appropriate under the circumstances. Adopting such a standard should not be difficult in this situation since these factors are already routinely considered in the "willfulness" context. See Fletcher, 928 F.2d at 501-02 (holding that "the trier of fact may properly consider the general educational background and expertise of the defendant as bearing on the defendant's ability to form the requisite willful intent"); see also United States v. Shields, 642 F.2d 230 (8th Cir.) ("Evidence of Shields' prior filing and taxpaying history, and IRS attempts to explain the legal requirements to him are sufficient to sustain the jury's finding that Shields was aware of his legal obligations imposed by the tax laws and intentionally chose not to comply with them."), cert. denied, 454 U.S. 848 (1981); United States v. MacLeod, 436 F.2d 947, 949 (8th Cir.) ("The government . . need not produce direct evidence of guilty intent. It can establish a willful violation . . . by circumstantial evidence alone."), cert. denied, 402 U.S. 907 (1971). Resort to the standard Form 1040 instructions should be sufficient for most taxpayers, who have no technical background or training in tax issues or accounting.

${ }^{83}$ Graetz \& Wilde, supra note 7, at 359. 
the expanded reporting requirements, as some have suggested, would significantly alleviate this problem. ${ }^{84}$ For example, if the taxpayer receives a Form 1099 or other information notice in the mail, its arrival should prompt the taxpayer to ask: "Why did I receive this form?" Once the thought processes are triggered, the steps taken should be the same as in the deduction context. Thus, the mechanics of the existing tax system appear quite conducive to a "recklessness" standard of liability.

Importing a "due diligence" requirement to the tax system should also work well to protect the innocent and the truly diligent. Virtually all potential jurors for a criminal tax prosecution are subject to the tax laws. This commonality with the defendant should allow the jury to judge the defendant's conduct fairly, and determine whether the defendant was truly diligent under contemporary notions of what is "diligent" under the circumstances.

Another question that should be asked in judging the propriety of criminally punishing the reckless noncomplier is whether it will really help to improve compliance. With regard to taxpayers already engaged in acts similar to those of the "reckless complier," empirical evidence indicates that it should. ${ }^{85}$ There is also, however, a strong argument to be made that expanding liability would have positive effects on all taxpayers, not just those directly affected by the expansion. It is commonly accepted that a general perception of growing noncompliance can directly affect an honest taxpayer's decision whether to remain honest in later years. ${ }^{86}$ In other words, honest taxpaying, in some repects, can be viewed as an act of faith-a taxpayer does her public duty in the hope that her fellow members will also comply. ${ }^{87}$ Theoretically, then, the

${ }^{84}$ See supra notes 18-20 and accompanying text.

${ }^{85}$ See supra note 24 (discussing the empirical evidence concerning the deterrent effect of increasing the perceived risk of criminal prosecution). This effect assumes that information concerning the expansion of liability would be relayed to the taxpaying public so that the perceived risk of prosecution would increase.

${ }^{86}$ See ABA COMPLIANCE REPORT, supra note 6, at 8 (" $[\mathrm{T}]$ ax cheating in turn feeds upon itself and further contributes to that decline . . . . If citizens continue to cheat with impunity, honest taxpayers will increasingly ask themselves how high a price they are willing to pay for their honesty."). These statements would appear to have equal force with respect to lax reporting. Cf. id. at 56 n.16 (noting that "cheating" is broader than the current legal definition of "fraud" or "evasion")).

${ }^{87}$ Others have come to similar conclusions on this point. See Melia, supra note 79 , at 1310 ("Evidence suggests that the strength of the commitment [of honest taxpayers] to comply is influenced by whether taxpayers believe that other taxpayers are also complying. In essence, taxpayers are saying 'if you pay your taxes, I'll pay mine; but if you cheat, I'll cheat, too." (citing HANS VAN DEN DOEL, DEMOCRACY AND 
expansion of liability would not only deter those already adopting lax reporting habits, it would be positive reinforcement for the honest and diligent taxpayers looking for a reaffirmation of their hopes.

Finally, there is a normative argument to be made for the propriety of punishing the reckless noncomplier. The issue is whether a lack of diligence in complying with the tax laws is deserving of criminal punishment. The answer to this question requires an analysis of both the gravity of the harm and the culpability of the actor. ${ }^{88}$

The gravity of the harm caused by noncompliance with the tax laws is highly debatable. For some, noncompliance or tax evasion simply represents a "victimless" ${ }^{\text {} 89}$ act of self-interest. ${ }^{90}$ In fact, as indicated previously, the Court, in Spies $v$. United States, ${ }^{91}$ articulated the proposition that a taxpayer's understatement of a tax liability was not much different from defaulting on a private debt. ${ }^{92}$ This Comment, however, takes the view that noncompliance is by no means "victimless." As one researcher has stated, the victims of noncompliance "are honest taxpayers, who must shoulder more of the tax burden, and citizens dependent upon public services that may be underfunded due to tax evasion. ${ }^{n 9}$ Although these victims are "not immediately apparent to many taxpayers,"

Welfare Economics (1979) and Michael Laver, The Politics of Private Desires (1981))).

${ }^{88}$ See, e.g., Herbert Packer, The Limits of the Criminal Sanction 17, 17-34 (1963) ("The rationale of the criminal law rests on three concepts: offense, guilt, and punishment."); Michael B. Metzger, Corporate Criminal Liability for Defective Products: Policies, Problems, and Prospects, 73 GEO. L.J. 1, 6-12 (1984) (analyzing various theories of criminal punishment in the context of products liability).

${ }^{89}$ See, e.g., Benjamin B. Sendor, Crime as Communication: An Interpretive Theory of the Insanity Defense and the Mental Elements of Crime, 74 GEO. L.J. 1371, 1399 n.128 (1985) (including tax evasion among the class of "victimless" crimes); Evan Haglund, Note, Impeaching the Underworld Informant, 63 S. CAL. L. REV. 1407, 1411 (1990) (same); see also ABA COMPLIANCE REPORT, supra note 6, at 21 (acknowledging that "[t]ax compliance norms are not rooted in basic social values about harming or violating the rights of others").

${ }^{90}$ See Moore, supra note 71 , at $275,280-82$ (hypothesizing that evasion is motivated by self-interest).

91317 U.S. 492 (1943).

92 For a discussion of the holding and rationale of Spies, see supra notes $49-51$ and accompanying text.

${ }^{93}$ Melia, supra note 79, at 1311; see also BALTER, supra note 3 , at 11 (" $[\mathrm{H}] \mathrm{e}$ who does not pay his legally due share of taxes, is automatically shifting his share, and thus adding to the already heavy burden of the honest taxpayer.").

${ }^{94}$ ABA COMPLIANCE REPORT, supra note 6, at 21. 
they do exist. A noncompliant, moreover, cannot be viewed in splendid isolation. Growing noncompliance will have a tendency to "snowball," and erode further "the moral fabric that sustains our voluntary tax assessment system. ${ }^{\prime 95}$ It sets a dangerous example for others to follow; it potentially leads the honest taxpayer astray. ${ }^{96}$ Noncompliers must shoulder part of the responsibility for contributing to the low level of compliance morality and discouraging other honest taxpayers from performing their duties diligently. As such, the harm imposed by the reckless noncomplier on the public trust and fellow citizens is simply greater than that imposed by a defaulting debtor. Consequently, the reckless noncomplier is deserving of more punishment.

The culpability of the reckless noncomplier, while admittedly less than that of the intentional evader, may also be deserving criminal punishment. Given the complexity of the tax laws ${ }^{97}$ and the frequency with which they change, ${ }^{98}$ the reckless taxpayer who

95 Id. at 8.

96 As one researcher has noted:

Noncompliance is likely to be an accelerating social process. Reports of an increasing degree of noncompliance have the effect of diminishing others' fears about the perceived risks of underpayment and thereby increase the likelihood of even more widespread noncompliance. Concern about the long-term consequences of this cascading process arise from the fact that the governmental benefits of preventing noncompliance go well beyond the actual revenues collected; the benefits include the discounted value of all future revenues that might otherwise be lost because of evasion.

Alfred Blumstein, Models for Structuring Taxpayer Compliance, in INCOME TAX COMPLIANCE, supra note 21, at 159, 167.

${ }^{97}$ See, e.g., James S. Eustice, Tax Complexity and the Tax Practitioner, 45 TAX L. REv. $7,11-20$ (1989) (discussing the sources and causes of complexity, and the roles of Congress, the Treasury, the tax bar, and educators in perpetuating the system); $M a k e$ Risks High Enough, supra note 6, at 47 (statement of Roscoe L. Egger, Jr., thenCommissioner of Internal Revenue discussing the Service's attempts to simplify the tax law and tax forms); Sidney I. Roberts et al., A Report on Complexity and the Income Tax, 27 TAX. L. REV. 325, 327 (1972) (addressing complexity of the law); Laura Saunders, One Man's Problem Is Another's Opportunity, FORBES, Mar. 7, 1988, at 105-06 (noting the complexity in the tax law that exists even after the "simplification" efforts of the 1986 Tax Reform Act). Although some see simplification as an answer to the compliance problem, see, e.g., Dorgan, supra note 8, at 927 (positing that taxpayers who understand their obligations are more likely to pay them in full), others see the complexity as costs of equity and fairness, see Finagling on Taxes Approaching the Crisis Stage, PR NewSWIRE, Jan. 9, 1981, available in LEXIS, Nexis Library, PRNews File (quoting Michael J. Graetz as stating that complexity in the tax law "is often the result of overzealous efforts to be fair").

${ }^{98}$ See, e.g., Gordon D. Henderson, Controlling Hyperlexis-The Most Important "Law and ...", 43 TAX LAw. 177, 192 \& n.49 (1989) (noting that there have been major revisions in the federal tax law "almost every year in the last decade"). 
chooses not to investigate her uncertainties regarding the law's requirements is fundamentally different from someone who attempts in good faith to comply fully with the law. Given that the tax law is by no means "inherently" known, one might safely assume that such a reckless individual is virtually certain to be in noncompliance with the law. The reckless noncomplier, therefore, is deliberately failing to satisfy the minimum level of conduct demanded of all citizens. As such, a reckless noncomplier is sufficiently culpable to justify criminal sanctions. Considering the nature of the tax system and the demands it places on citizens for it to function properly (mainly diligence), there would appear to be no impropriety in criminally punishing the reckless noncomplier.

\section{The Political Acceptability OF EXPanded Liability}

Despite the equitable basis for expanded liability, politicians and taxpayers alike would not likely be receptive to the expansion of criminal liability in the abstract. Expanding criminal liability to force compliance with existing laws would be thought by some to instill only fear and resentment in the taxpaying public, ${ }^{99}$ and thus would not be a good method of encouraging "voluntary" compliance. ${ }^{100}$ But when the proposal is analyzed in the proper context and framework, its advantages become clear. If these benefits are stressed, the proposal could easily become acceptable politically. After all, it is difficult to argue against requiring diligence in tax compliance. Using contemporary notions of tax policy, democracy, an enforcement procedure, this Part will evaluate the proposal as a tax compliance measure and seek to articulate its advantages and disadvantages.

99 See ABA COMPLIANCE REPORT, supra note 6, at 21 ("Those trying in good faith to comply may become resentful when they perceive punitive responses to instances where they misunderstood or misinterpreted the legal requirements.").

${ }^{100}$ See id. ("Strict and unreasonable enforcement can, in fact, contribute to undermining the policy goals which the rules are designed to enforce .... Alienation and increasing hostility can deprive the agency of cooperation and can increase enforcement costs."); see also supra note 71. 


\section{A. Expanded Liability as Tax Policy}

Under contemporary notions of tax policy, any suggestion to improve the integrity of the tax compliance system is evaluated by analyzing the extent to which it furthers five basic goals: increasing equity; (2) promoting administrative efficiency; (3) preserving taxpayer privacy interests; (4) maximizing revenue; and (5) minimizing the compliance burden on taxpayers and third parties. ${ }^{101}$ Applying these considerations to the proposal at hand, it promotes most of them.

The equity factor clearly favors adoption of the proposal. Generally, theorists consider two types of tax equity: horizontal and vertical. ${ }^{102}$ Horizontal equity refers to treating similarly situated taxpayers alike. ${ }^{103}$ Vertical equity describes the policy of having high-income taxpayers share a larger portion of the tax burden than lower-income taxpayers, and it is based largely on notions of "ability to pay. "104 Generally, both types of equity are offended when taxpayers incorrectly report their tax liabilities, ${ }^{105}$ and diligence would appear to have a direct connection to the accuracy of this reporting. Consider the case of two similarly situated taxpayers, with one taxpayer being very diligent in the preparation of her return and the other less so. In our system of taxation, the outcomes with respect to self-reported taxable income are likely to be very different. The diligent taxpayer is more likely to state income correctly while her counterpart either overstates or understates income. If both taxpayers are equally diligent, however, theory would suggest that the taxpayers would arrive at more equal income approximations, thus achieving greater horizontal equity. ${ }^{106}$

101 See Harris, supra note 2, at 532 (presenting the five criteria); see also John A. LeDuc, The Legislative Response of the 97th Congress to Tax Shelters, the Audit Lottery, and Other Forms of Intentional or Reckless Noncompliance, 18 TAX NoTES 363, 365 (1983).

102 For a general discussion of the equity concept and its role in tax policy, see MichaEl J. GRAETZ, Federal INCOME TAXATION: PRINCIPLES AND POLICIES 17-19 (2d ed. 1988).

103 See Harris, supra note 2, at 582.

104 See LeDuc, supra note 101, at 364. These vertical equity considerations are seen by some as fundamental to a just taxing system. See, e.g., RONALD PASQUARIELlo, TAX JUSTICE: SOCIAL AND MORAL ASPECTS OF AMERICAN TAX POLICY 44 (1985) (stating that, to most people, "tax justice . . . means taxing according to ability-topay $^{n}$.

${ }^{105}$ See Harris, supra note 2, at 532 (noting that uncorrected errors resulting in an incorrect statement of a taxpayer's tax liability offends the equity principle).

106 This example assumes that bath taxpayers have roughly equal abilities to 
Diligence proves similarly effective in improving vertical equity. Assume that two taxpayers, one with a large amount of income and another with less income, each compute their respective tax liabilities. Under the current somewhat progressive American income tax system, other things held equal, the high-income taxpayer should report a greater tax liability than her lower-income counterpart. If one or both of the taxpayers is reckless in the preparation of her return, however, the congressional scheme of progressivity is likely to be frustrated, with one or both of them overstating or understating income or deductions.

Administrative efficiency considerations also support the proposal. Administrative efficiency "requires an analysis of whether the proposed change would lead to more self-reporting without the use of Service intervention. ${ }^{107}$ Currently, the compliance system is enormously over-burdened, ${ }^{108}$ and revenue authorities have many more returns flow through the system each year than they can afford to audit. ${ }^{109}$ Should the proposal achieve its desired consequences-promoting diligence-it could do much to relieve some of that burden (at least in the enforcement area). The expansion of liability, to be effective, may require the Service to conduct more investigations and, thus, expend more resources in the short-term. Yet, the proposal could possibly have other consequences. The expansion of criminal liability could, for example, produce a sense of anxiety among taxpayers who would perceive themselves to be subject to a greater threat of criminal prosecution. This anxiety could force the Service to allocate a greater portion of its resources to answering the questions of confused taxpayers searching for solutions to their problems. But over time, this burden would subside as veteran taxpayers become more comfortable with the tax law. Moreover, improving compliance through expanded response to taxpayer questions should be preferred over improving compliance by increasing more expensive and intrusive enforcement

compute their respective tax liabilities.

${ }^{107}$ Harris, supra note 2, at 533 . This concept of administrative efficiency should be distinguished from the unrelated concept of efficiency as a goal of tax policy and legislation. For a discussion of this latter notion, see GRAETZ, supra note 102, at 17.

${ }^{108}$ See, e.g., Long \& Burnham, supra note 21, at 747 (noting that lack of enforcement resources constrains the Service's ability to collect taxes).

${ }^{109}$ See Harris, supra note 2, at $515 \mathrm{n} .3$ (citing the Commissioner's and Chief Counsel's Annual Reports of the Internal Revenue Service, which states that only $1.3 \%$ of the total returns filed in 1984 were audited); see also Steuerle, supra note 18, at 859 (noting that only $.8 \%$ of individual taxpayers' returns were audited in 1990). 
measures, such as individual audits and the subsequent correction of errors through amended returns.

Although at first glance the effects on taxpayer privacy interests may appear to be neutral, over the long term the proposal would do much to prevent further intrusion into taxpayer privacy. By forcing taxpayers to be diligent, the proposal would encourage taxpayers to make the disclosures now required under current law more accurately, rather than forcing them to make more disclosures. On a deeper level, however, greater compliance with existing disclosure requirements may protect against future privacy intrusions. As one commentator has noted, "[w]ithout much question, the less accurate the initial self-reporting by taxpayers, the greater the need or incentive for the Service to inquire further into taxpayer affairs." 110 Thus, although the taxpayer would be under a greater threat of prosecution and public exposure for her lack of diligence, all things considered, the proposal's effects on privacy would be favorable.

With regard to the revenue criterion, the effect of the proposal is difficult to gauge. It is readily admitted that some noncompliance contained in the tax gap is the result of "taxpayer negligence and lack of due care."111 It is also admitted, however, that some of this noncompliance overstates rather than understates taxable income. ${ }^{112}$ Over the long term, the increase in compliance should bolster revenues by improving general compliance morality, allowing the revenue system to expand to realize its full potential, and permitting the Service ultimately to allocate its enforcement resources more efficiently. ${ }^{113}$

And finally, to implement the program fully in the fairest possible manner, the compliance burden on third parties, as well as taxpayers, would probably have to be increased. Information reporting is already becoming a growing part of the compliance system. ${ }^{114}$ As an integral part of fairly enforcing the proposed

${ }^{110}$ Harris, supra note 2, at 534.

111 ABA COMPLIANCE REPORT, supra note 6, at 2.

112 Throughout the $1970 \mathrm{~s}$ and early $1980 \mathrm{~s}$, the IRS has determined that, of the income tax returns not in compliance with the law, $10 \%$ reflected overstatements of income and 90\% reflected understatements. See KINSEY, supra note 29, at 1, 4-8 \& tbl. 1; see also SMITH \& KINSEY, supra note 79, at 4 (noting that about $8 \%$ of taxpayers overpay unintentionally).

${ }^{113} C$ f. Steuerle, supra note 18, at 860 (noting that audits are now being replaced by reporting and withholding mechanisms).

${ }_{114}$ See id. at 859-60; see also Long \& Burnham, supra note 21, at 744 (discussing how the Service researches income tax noncompliance). 
expansion, such information reporting would place a greater burden on third parties to provide data about, and notice to, relevant taxpayers. But the significance of the incremental burden, in light of the present tax gap and the existing proposals for expanded reporting already on the table, appear justified when considered in light of the potential benefits-more accurate tax returns and a more compliance-oriented public.

\section{B. Expansion as Democratic Reinforcement}

Aside from comporting with contemporary notions of tax policy or considerations of the compliance system generally, encouraging taxpayers to search for answers to their tax questions and become more familiar with the law could have other positive consequences. One is the improvement and promotion of the democratic process. ${ }^{115}$

The tax laws are notoriously complex, ${ }^{116}$ and under our present regime taxpayers have become enormously alienated, frustrated, and discouraged. ${ }^{117}$ As a result, large portions of society are increasingly unfamiliar with the tax laws. The effective functioning of a representative government, however, is premised on an informed electorate; that electorate seems virtually nonexistent with respect to the tax laws and tax policy.

Forcing taxpayers to wrestle with the tax laws diligently should encourage them to acquire a better understanding of the general structure of the tax law, its strengths and its weaknesses. This knowledge, in turn, would help the representative bodies of government respond to taxpayer concerns. Granted, the lag time before the average taxpayer is capable of making an informed recommendation concerning tax policy may be lengthy, and it is safe to assume that only a very few will grasp a full knowledge of the Code, but in the long term, the effects could be dramatic. The

115 The notion that increased compliance is beneficial to the democratic process and a democratic society has been accepted by others. See LeDuc, supra note 2, at 1029 n.7 (stating that "compliance with law is a good in any democratic society").

116 See supra note 97.

${ }^{117}$ See, e.g., Finagling on Taxes Approaching the Crisis Stage, supra note 97 (noting that complexity has "sent hordes of taxpayers scurrying to tax-preparation professionals") (quoting Michael J. Graetz); Make Risks High Enough, supra note 6, at 47 (stating that, as a result of the complexity of the system, many taxpayers get "discouraged" and "they just put anything down on their return and send it in") (statement of Roscoe L. Egger, Jr., then-Commissioner of Internal Revenue). 
alternative-an increasingly frustrated and disconcerted public-is certainly less desirable.

\section{The Proposal as an Enforcement Mechanism}

The concerns most likely to be at the forefront of public consciousness are the regularity with which the government would use its new tool and the potential for abuse. However, a few basic observations should lay this concern to rest.

Historically, the decision to prosecute a tax case has been made only after a careful consideration of the facts and circumstances of the taxpayer's case. ${ }^{118}$ Deterrence is the primary goal: "tax prosecutions are not undertaken to collect revenue, but rather to demonstrate to taxpayers generally that tax evasion does not pay."119 Additionally, as one prosecuting attorney has stated, "the government takes very few tax disputes to indictment, only those with which it can send a message. ${ }^{p 120}$ There is nothing to suggest that this policy would be altered under a recklessness standard. In fact, for the expansion to have its desired effect, selective prosecution must be continued.

Traditionally, three factors have produced the extremely low rate of criminal prosecutions. First, the costs associated with a criminal investigation and prosecution make it one of the least efficient methods of realizing revenue on an individual taxpayer basis. These costs would most likely remain constant, despite an alteration of the standard of liability. Second, the negative publicity generated by losing a tax prosecution case would continue to provide a strong incentive to forego prosecution of questionable cases. ${ }^{121}$ So long as the government is perceived as merely enforcing the laws as necessary to protect the public fisc, and not as

118 See BALTER, supra note 3, at 24-26 (listing the alternative actions that the government may take in conducting a tax investigation, and concluding that the decision to prosecute will be made in cases only where there has been "a very careful inquiry into every phase of the case and after many stages of review"); Richard $M$. Roberts, Administrative Processes After Investigation Is Completed, in DEFENDING TAX FraUd PROSEcutTIONS 63, 64-92 (PLI Crim. Law \& Urban Probs. Transcript Series No. $2,1970)$ (detailing the procedures taken in making the decision to prosecute).

119 Roberts, supra note 118, at 86.

${ }^{120}$ Alan Abrahamson, Not Everyone Just Complains About Taxes, L.A. TIMEs (San Diego County ed.), Aug. 18, 1991, at B1, available in LEXIS, Nexis Library, Currnt File.

${ }^{121}$ See Roberts, supra note 118, at 86 ("'The Government is quite selective in those it prosecutes.... [W] [Wen we lose a case the desired deterrent effect is not produced." (quoting a member of the Department of Justice's Tax Division)). 
"ganging up" on innocent taxpayers, the public will support the government and its efforts. Once the government crosses this line, however, it will quickly lose both the respect and cooperation of taxpayers. Third, and probably most importantly, juries would still be composed of fellow taxpayers. In the event of an overly zealous prosecution, jury oversensitivity would be a real consideration. 122

Finally, civil penalties, by providing an intermediate level of punishment, would play an important role in preventing prosecutions on a wholesale basis. ${ }^{123}$ Accordingly, it is highly unlikely that the Service would begin wholesale prosecutions simply because reckless noncompliance became a crime.

\section{CONCLUSION}

In times of drastic budget cuts and growing annual federal deficits, the problem of noncompliance with the tax laws assumes an ever-increasing importance. As one expert has expressed his concern, "[n]ations have declined because they were defeated in war, lost their economic advantage, or suffered a failure of leadership. The United States may become the first great power in history to falter because it lost its ability to collect taxes." 124 The traditional responses have been largely unable to deal with the problem, and despite congressional revisions in the civil penalty structure, ${ }^{125}$ the tax gap continues to grow. Answers to a problem of this magnitude do not come easily, but one thing that appears obvious is that the response should be extraordinary.

The responsibilities of citizenship include the duty to take the laws seriously. In the taxation context, this means that one must be diligent and uphold the public trust by attempting in good faith to perform duties of self-assessment. Unfortunately, the criminal provisions of the Code do little to require a taxpayer to make a good faith effort, and may even create a disincentive for the taxpayer to do so.

122 This is especially possible with respect to the "due diligence" requirement. See supra note 82 and accompanying text.

${ }^{123}$ See generally SALTZMAN \& KAPLAN, supra note $32, \mathbb{I} 1.01$, at $1-1$ to $1-3$ (discussing the general history of civil penalty provisions); see also BALTER, supra note 3, at 25 (discussing the Service's use of civil penalties as an intermediate form of deterrence and punishment).

124 Hugh Caulkins, Foreword to INCOME TAX COMPLIANCE, supra note 21, at viii.

125 See Dubin et al., supra note 18, at 787-88 (outlining legislation of the 1980s with regard to civil penalties). 
The criminal provisions of the Code should be expanded to require diligence in reporting and to demand that the duty of selfreporting be taken seriously. This expansion should be implemented only as part of an integrated plan involving other mechanisms. With greater information reporting, increased Service-sponsored educational programs, and direct appeals to the taxpaying public to perform their duties diligently, an expansion of criminal liability to reach "reckless noncompliance" could be implemented in a way that is fair, systematically compatible, and politically acceptable. The general public's recognition of that fact could be an important first step towards improving the noncompliance problem. 
.

. 